\title{
Biological Factors Contributing to the Development of Homosexuality: A Systematic Review of the Literature
}

\author{
Idalia Maciel ${ }^{1 *}$
}

\begin{abstract}
Homosexuality is often considered to be a "moral issue" in society, particularly in religious groups; whether it should be considered socially acceptable is an ongoing debate that has affected many. Recently, scientific evidence has suggested that there seem to be biological bases of homosexuality. This would mean that individuals do not have a choice regarding their sexual orientation, making it illogical for it to be considered a "sin.". Whether this is true or not, its investigation is an important issue in the field of psychology, as it is evident that, while homosexuality greatly affects an individual's personality and behavior, its origins are still unclear. In the study of the research question, current theories and corresponding evidence on homosexuality's biological origins are investigated. The evidence discussed originates from a range of sources including journal articles, books, academic websites and psychological studies. These included twin studies, experiments, brain scans, observational studies, DNA linkage analysis and natural experiments. These allowed the researcher to evaluate the ways in which homosexuality can be attributed to biological factors and the way these interact with other elements. The biological factors analyzed were brain structures, the differences of the use of the brain between homosexuals and heterosexuals, and finally the fraternal birth-order effect. These biological factors are linked to the environmental factors in Bem's exotic-becomes-erotic theory. Finally, included is an evaluation of these biological factors through the referencing of female sexuality and its apparent lack of biological causes. This paper concludes that the way in which biological factors contribute to the development of homosexuality lies in providing a predisposition that will later develop into an active sexual orientation in sexual maturity.

\section{Keywords}

Homosexuality - Biological Factors - Genetic Factors - Exotic-becomes-Erotic

${ }^{1}$ Department of Psychology, University of North Texas

*Faculty Mentor: Dr. Michael Barnett, Department of Psychology
\end{abstract}

\section{Contents}

1 Introduction

2 Biological Factors

2.1 Brain Anatomy . . . . . . . . . . . . . . . 2

2.2 Genetics . . . . . . . . . . . . . . . . . . 3

2.3 Fraternal Birth Order Effect Theory . . . . . . . . . 3

3 Link to Environmental Factors

3.1 Gender Conformity \& Exotic-Becomes-Erotic . . . 4

4 Female Sexuality

5 Tabular Summary of Findings

6 Conclusion

Author Biography

References

\section{Introduction}

1

2

(1)
the Diagnostic and Statistical Manual of Mental Disorders until 1973. The studies that had illustrated it as a mental illness had been carried out on homosexual mental patients in wards [2] having patients who already had some sort of illness, therefore making it unsurprising that they were found to be mentally imbalanced. After more systematic studies were carried out on the topic [3], research data allowed for homosexuality no longer to be classified as a mental illness, as there was not enough credible evidence demonstrating as much. Although most mental-health specialists agreed with this decision, many people opposed it, and so the study of the 6 causes of homosexuality and possible "treatment" has become 6 
of either nature or nurture. The "nature" component refers to the biological factors of an individual, while "nurture" applies to the environment and sociocultural factors to which we are exposed, mainly in childhood [4]. Currently, scientists believe that neither of the two explanations fully describes the etiology of homosexuality. The question appears to be of an interactionist nature-not whether biological factors affect sexual orientation, but how they do and the extent of their effect. Evidence seems to show that homosexuality is, to a large extent, the result of the pre-determinism of biological factors interacting with sociocultural ones, however, no consensus has been reached as to how big of a part each plays. As the investigation of this topic would be very broad, since large amounts of research have been carried out in both the biological and environmental areas of the causes of homosexuality, the research question has been narrowed down to focus on the biological factors. This leads to the research question: In what ways do biological factors contribute to the development of homosexuality? The current consensus among researchers seems to be that biological factors contribute to the development of homosexuality by providing a biological predisposition to it, but that they cannot be established as a direct or sole cause of homosexuality.

\section{Biological Factors}

\subsection{Brain Anatomy}

To begin with the physical and thus the more tangible of the biological factors, we will discuss the differences between heterosexual and homosexual individuals in brain anatomy. These have been thought to account for the differences in sexuality between the two groups. Simon LeVay's post-mortem autopsy study comparing the brains of homosexuals and heterosexuals pioneered the study of brain structures and their possible link to sexual orientation [5]. He found that homosexuals have a decreased size of the third interstitial nucleus (INAH3), a group of neurons in the hypothalamus structure of the brain. The hypothalamus is the area of the brain which in addition to other functions, controls sexuality. The INAH3 is believed to be linked with sexual behavior as has been found in experiments on animals [6]. Intriguingly, although the INAH3 has been found to be larger in men than in women, the findings of this study showed the size of the INAH3 in homosexuals to be quite similar to that of women. This and the corresponding studies on animals on the region allowed LeVay to come to the conclusion that it is most probable that the INAH3 is one of many areas of the brain that are involved in sexuality [7]. These findings provide support for the idea that physiological differences between homosexuals and heterosexuals in the brain may account for their difference in sexual orientation.

Another anatomical difference found between the brains of heterosexual and homosexual individuals is the size of the suprachiasmatic nucleus ( $\mathrm{SCN}$ ) of the hypothalamus. In the brain, the suprachiasmatic nucleus controls our sleep cycles but its role in sexuality is still unknown. This area of the brain has been shown to be about twice the size in homosexual males than in heterosexual males [8] and, like the INAH3, to be of similar size to that of women [9]. In an attempt to explain his results, Swaab and colleagues manipulated the sex hormones of rats by using the aromatase inhibitor ATD, to prevent aromatization, the process of changing testosterone into estrogen. This was done so that testosterone would have less of an effect on the development of the brain. Interestingly, when they reached sexual maturity, the rats demonstrated bisexual behavior. Swaab concluded that the difference in the volume of the SCN could be a result of the interaction of sex hormones with the brain from an early age. One of the criticisms aimed at his research has been that there was a significant lack of control of the variables and that the rats' bisexual behavior could have been influenced by such other factors such as the lack of testosterone upon another area or something completely unrelated.

With regard to the aforementioned studies, it is not possible to establish whether the differences in brain structures were the result of homosexuality or a cause of it. Longitudinal studies using imaging techniques with babies/children throughout their development would be necessary to observe whether the brain differences existed before the homosexual preference. However, it would not be possible to tell which children would grow up to be homosexual, and so the sample group would be very difficult if not impossible to identify. Another issue is the question of whether environmental factors could contribute to the brain differences. It is difficult to determine the extent of the effect of biological factors as opposed to environmental factors, since there is the possibility that one could affect the other in an interaction. Nevertheless, the fact that there are differences in brain structures between these sexual orientations is important to note, as brain anatomy is not a product of chance.

Not only does there seem to be a difference in the brain structure of homosexual individuals as compared to heterosexuals, but there also seems to be a difference in the way they actually use their brains. This was discovered through the use of the (electroencephalogram (EEG), a brain scanning technique that measures brain waves by attaching small electrodes and wires to a person's head. ${ }^{1}$ The EEG detects brain waves and records them on a computer screen in order for these to be seen. EEG studies have shown that homosexuals produce a higher amount of brain waves in the left hemisphere than heterosexuals do when performing spatial tasks, while also showing less activity in the right hemisphere when performing verbal tasks [10]. Also playing a role in the exploration of brain pattern differences between heterosexuals and homosexuals are fMRI studies. It appears that in the experience of disgust as a result of erotic stimuli that are "sexually disgusting" for the individual—as would be determined by their sexual orientation and the sex of those featured in the

\footnotetext{
${ }^{1}$ EEG definition - tests and procedures - Mayo Clinic. Retrieved 24 November 2014, from http://www.mayoclinic.org/testsprocedures/eeg/basics/definition/prc-20014093.
} 
stimuli-there is brain activation that is similar regardless of sexual orientation, and some that is specific to orientation [11]. That is, in homosexuals it was found that there was more brain activation in the left medial frontal gyrus than in that of heterosexuals, while heterosexual men had greater activation in the left cuneus in comparison to gay men when sexually disgusted. This provides support for the concept that there are functional differences between homosexuals and heterosexuals [10]. These variations seem to suggest that there may be biological differences between the sexual orientations, which might also cause their mental processes to be different. By the same token, it could also be that mental processes play a part in the etiology of sexual orientation. Clearly, it is very difficult to determine a cause-and-effect relationship in studies such as these since correlation cannot indicate causation and it is ultimately possible that these differences in brain structures or their uses might have nothing to do with the differences in sexual orientation. Nevertheless, the findings provide support for the idea that there are biological differences between homosexuals and heterosexuals, and thus contribute to the journey of understanding sexual orientation.

\subsection{Genetics}

A second biological theory suggests that the genetic makeup of individuals predisposes them to homosexuality, and thus their sexual orientation is determined before birth. Bailey and Pillard's study titled, "A Genetic Study of Male Sexual Orientation" revealed a higher concordance rate for homosexuality between monozygotic (identical) twins when compared to dizygotic (fraternal) twins, who share only half of their genetic makeup [12]. The concordance rate refers to the percentage to which a characteristic is expressed in both twins. The comparison of these percentages between monozygotic and dizygotic twins could shed some light on the extent to which biological factors might be involved in the cause of a characteristic. If the concordance rate is higher for monozygotic twins, it suggests that the behavior may most likely be due to genetics. On the other hand, if the concordance rate of the monozygotic and dizygotic twins is similar, it could indicate that genetics have little to no effect on the characteristic. The results of Bailey and Pillard's study showed that, for homosexuality, there was a concordance rate of $52 \%$ between monozygotic twins (MZ) and 22\% for dizygotic (DZ) twins. Whitam, Diamond and Martin's [13] study at Arizona State University found a concordance rate of $65.8 \%$ for $\mathrm{MZ}$ twins and $30.4 \%$ for DZ twins. In addition, Hershberger's meta-analysis of eight twin studies on the topic concluded that MZ twins had a significantly higher concordance rate for homosexuality than did the DZ twins in six of the studies. These data suggest that there is a genetic factor that influences homosexuality [14].

The higher concordance rates for monozygotic twins in all of these studies are significant because identical twins share the same genetic makeup. Sharing the same genetic makeup and having the twins both be homosexual more than half of the time strongly suggests that our genes are a part of the formation of sexual orientation. In addition, the fact that the monozygotic concordance rate was 30 percentage points higher than that of dizygotic twins, who only share half of their genes, reiterates this point. Equally important, is the lack of a $100 \%$ concordance rate between the monozygotic twins. This finding suggests that homosexuality is not solely based on biological factors. Were this the case, both monozygotic twins, being biologically the same in all of the pairs studied, would be homosexual. The fact that this was not the case shows that there are other factors besides genetic ones that affect a person's sexual orientation. By the same token, too much weight should not be placed upon these findings, as twin studies have several limitations such as the self-selections bias where homosexuals with gay twin siblings are most likely to volunteer to participate, thus affecting the validity of the results [6]. Thus, other forms of studies on the genetics of homosexuality should be conducted, such as DNA linkage analysis.

DNA linkage analysis refers to the use of DNA sequences, whose position is known in the genome, to find the rough location of a mutation in a gene. Investigators then track the inheritance of this mutation within a family [15]. A study carried out by Hamer, Hu, Magnuson, Hu and Pattatucci, using the DNA linkage analysis of blood and saliva samples from homosexual siblings - concluded that the maternally linked (inherited from the mother) chromosome band Xq28 is connected to homosexuality [16]. The researchers arrived at this conclusion as thirty-three of forty homosexual pairs of siblings were found to be concordant for the alleles in the Xq28 genetic marker. These findings led Hamer to state that there was $99.5 \%$ certainty that there is a gene, or several genes, on the $\mathrm{X}$ chromosome that cause a predisposition for heterosexuality. His findings caused a frenzy in the media which incorrectly claimed that a "gay gene" had been identified.

\subsection{Fraternal Birth Order Effect Theory}

Beyond genetic-based hypotheses, there have been other theories, specifically about how homosexuality may be a result of events before birth. According to the fraternal birth-ordereffect theory, the higher the number of older brothers a male has, the higher the chance that he will be a homosexual [17]. Interestingly, this possibility rises by a third for every older brother, as was illustrated by Blanchard and Bogaert's study [18]. The reason for this phenomenon is best explained by the maternal immunization hypothesis. According to this, when a mother is pregnant with a male, she produces an antigen, a substance that generates an immune response, against the fetus' Y chromosome. With the birth of each male, there is an increase of immunization in the mother's system, which defends itself against the antigen, causing an immune reaction that affects the brain of the fetus and the sexual differentiation of the brain [6].

There is very little evidence to support the maternal immunization hypothesis, as most appearance of it in studies is 
minute and probably more due to chance [6]. Much of the evidence used to support it relies on assumptions and other ideas that have not been proven. For one, it has not been demonstrated that there is an antigen that codes for heterosexuality, thus casting significant doubt upon the theory as a whole. In addition, a theory that suggests that homosexuality is the result of an error of the human immune system also implies that homosexuality is a dysfunction of a biological process. In other words, it could be referred to as a birth "defect." Although this is the correct biological term for the condition, the expression has negative connotations, which have given anti-gay groups an opportunity to claim that homosexuality is unnatural and requires "treatment."

In the evaluation of the implications of these studies, it must be kept in mind that correlation does not mean causation. The fact that biological factors do seem to affect sexual orientation should not be misinterpreted to mean that biology is the only cause. Worthy of note, indications of biological influence should not be interpreted as the reductionist suggestion that there is a "gay gene." The idea that one gene could account for an individual's homosexuality or any other form of sexual orientation is illogical since, as Corvino states, "Genes in themselves cannot directly specify any behavior or psychological phenomena," since there are many pathways between genetic makeup and actually expressed behavior [4]. This is, however, not to say that genes do not have an effect upon homosexuality. It is only more likely that, instead of one gene singlehandedly coding for sexual orientation, there are several genes that code for different characteristics that together form sexual orientation [6]. It is clearly much more complex than this, as having a predisposition does not necessarily mean that a characteristic will develop; there must be environmental triggers. Biology sets up the stage for homosexuality, but it cannot do it on its own.

\section{Link to Environmental Factors}

\subsection{Gender Conformity \& Exotic-Becomes-Erotic}

A biological link to environmental factors seems a more plausible cause of homosexuality than a "gay gene," as it is unlikely that a complex human trait like homosexuality could be coded for by one single gene. There is a theory that has a biological basis that takes this into account the fact that, where instead of genes directly affecting sexual orientation, they might affect the behavior indirectly by coding for temperaments such as aggression [17]. Such a coding would predispose us to our preferred pastimes (e.g. wrestling), style of interaction with others, and preferred types of friends, eventually disposing us toward whom we find attractive and our overall sexual orientation. This theory is referred to as the exotic-becomes-erotic theory, and it begins with gender conformity or nonconformity in childhood.

According to sociologist, Sandra Bem, who identified and defined the concept of gender conformity, we live in a society that is gender polarized [19]. In it, male and female genders are considered to be opposites, with activities classified as "masculine" or "feminine." The adaptation and matching of a person's behavior to fit with the stereotypes of their gender and the gender polarizing practices is referred to as gender conformity. This consists of girls' playing with dolls and boys playing with toy cars. Because they are considered polar-opposites, it goes against social norms for a female to carry out masculine activities and vice versa. Failure to take part in these activities and instead participate in those that are typically of the opposite sex is referred to as gender nonconformity. Daryl Bem, the establisher of the exoticbecomes-erotic theory, believes that gender nonconformity in childhood can lead to the development of homosexuality and thus that genetics are involved in sexual orientation, just not directly.

In the exotic-becomes-erotic theory, homosexuality can only occur under gender differentiation and in non-conformity. The basic idea of the theory is that individuals will be attracted to the sex opposite of the one that they interacted with most in childhood, as this sex is unknown to them, and the curiosity that develops from the mysteriousness of this sex causes high physiological arousal, which develops into romantic and sexual attraction. According to the theory, children with similar pastimes will play together on the playground as a result of their genes; therefore, most girls will be naturally drawn to more feminine games such as jump rope and playing on the swings, and so will play with other girls. Meanwhile, boys are drawn to more masculine games such as rough-housing and playing tag, and so will end up playing mostly with other boys. However, when an individual participates in gender nonconforming behaviors, they become involved in activities typical of the opposite sex, and thus spend most of their time with this sex. The sex we do not spend time with then begins to spark our interest since we know nothing about them, making them "exotic" to us. To satisfy this curiosity, we will begin to spend time with the opposite sex attempting to find ways to interact with them, but because we never had before, we do so in unusual ways such as teasing and fighting until it develops into romantic and sexual, or otherwise known as erotic, feelings [4].

As a result of this, psychologists such as Bem believe that many children show signs of their homosexuality by their preferred colors, clothes and costumes even before developing an active attraction to the same sex [4]. Research done by Bell and colleagues, now known as the San Francisco Study, has shown that "childhood gender conformity or nonconformity was not only the strongest but also the only significant childhood predictor of later sexual orientation for both men and women" [17]. Further studies show that homosexual individuals, whether male or female, are more likely to have taken part in or have had gender nonconforming interests and activities in their childhood, than heterosexual participants. In addition, homosexuals were found to have much lower levels of aggression as children, a typically masculine characteristic, than heterosexuals. Support for the theory was further illustrated by the findings of a longitudinal study carried out 
by Adam and Green where, of the children studied, $75 \%$ of gender nonconforming boys became homosexual or bisexual while only $4 \%$ of gender conforming boys did. In addition, studies carried out on homosexual and heterosexual participants on the topic of gender conformity showed that $70 \%$ of gay men and lesbian women felt different from same-sex peers in childhood, while only $38 \%$ of heterosexual males and $51 \%$ of heterosexual females felt the same way [20].

Overall, the theory suggests that sexual orientation is a result of a biological predisposition, as it appears that genes may be responsible for gender nonconformity, which in turn leads to homosexuality. Meanwhile the active sexual attraction takes place downstream as a result of environmental factors, demonstrating the interaction between environmental and biological factors to develop homosexuality.

However, there are studies that refute the idea that gender nonconformity has any correlation with the development of homosexuality, such as Bailey and Pillard's study [12]. This study found opposing results that indicated that childhood gender nonconformity did not link with the development of homosexuality in the future. This demonstrates that boys that seem to be atypically feminine, do not necessarily grow up to be gay, and that girls with masculine personalities do not necessarily grow up to be lesbian. Therefore, going against the idea that biological factors contribute to the development of homosexuality by coding of characteristics that will result in gender conforming or non-conforming behaviors.

\section{Female Sexuality}

However, most of the research on the biological bases of homosexuality has been conducted on males. This must be taken into account when evaluating the evidence and its implications because, although there have been many studies to show that homosexuality is biologically based, these studies lacked female homosexual presence. Thus they may only be illustrating causes of male homosexuality; this is particularly the case when other studies done on women show that females tend to have a very fluid and dynamic sexuality compared to men [6]. Thus, women are more likely than men are to experiment with their sexuality, and act upon attractions that do not fit in with their identified sexual orientation. For example a woman who identifies as a heterosexual and feels an attraction to another woman is more likely to act upon the attraction than is a heterosexual man is if he is attracted to a man [21]. This could be a result of a greater effect of social factors upon their sexuality than biological factors.

Studies show that female sexuality and sexual orientation do not seem to be as solidified and permanent as that of males and often changes as a result of sexual exploration or experimentation [21]. It has been found that many women do not necessarily feel that their sexuality is invariantly fixed and determined on one gender, and that a change in sexuality can come about as a result of experimentation, curiosity, and other social factors.

Of the studies that have investigated the biology of female homosexuality, such as brain imaging studies, sex differences have been found in the brain functions of men and women [22]. Sylva's study, the first to show category-specific sex differences via fMRI, provides further evidence for females' sexuality fluidity, as sexual arousal has been shown to be much less category-specific for females than it is for males-that is, females' sexual arousal is not targeted solely towards a category of people: males if heterosexual, or females if homosexual. Instead, their sexual arousal is undifferentiated between erotic stimuli featuring men or women, no matter their preferred sex according to their sexual orientation. Thus, it is shown that sexuality is a different experience for women than it is for men.

To fully understand the causes of homosexuality and avoid gender-biased conclusions, research must increase the presence of lesbians and females overall. In light of the differences that have been found, it might also be necessary to study female homosexuality and male homosexuality as completely separate phenomena in order to study it accurately. This would allow us to determine if there is a difference in the way biological and environmental factors contribute to the development of homosexuality between males and females as opposed to overgeneralizing findings.

\section{Tabular Summary of Findings}

Summary tables of the principle findings from the literature are shown below. The first two tables summarize the biological factors, while the third displays a summary of environmental factors.

\section{Conclusion}

Evidence collected in studies seems to suggest that biological factors such as genetics, contribute to the development of homosexuality by providing a biological predisposition to this sexual orientation. However, because there were no $100 \%$ concordance rates, discoveries of gay genes, or truly definitive findings that were consistent across the studies, the current conclusion is that it is not only biological factors that cause homosexuality and the extent of their effect is currently immeasurable. In addition, it appears that actual homosexual behavior is a result of these biological factors interacting with sociocultural factors, which allow it to develop and for the individual to choose to express these desires by adopting a homosexual identity. Thus, the most probable explanation is that the causes of homosexuality are biopsychosocial, where biological, psychological and sociological aspects all influence it to different degrees. It appears that in males, biological factors provide a basis for homosexuality that will be developed through psychosocial factors in the future. However, as the evidence of female sexuality has shown, it appears that these biological factors have less of a hold on female homosexuality and sexual behavior as a whole. Thus, the biological nature of homosexuality should not be overstated as in the current stance it appears that this may account more for the male 
homosexual community, than the homosexual community as a whole.

Although biological determinism seems to be the most likely cause, at least for male homosexuals, in reality we still know very little about the origins of sexual orientation, and like all theories, this one should be scrutinized and treated with caution until further research is done and a clearer understanding is reached. This is crucial as it is dangerous for people to get carried away with the idea that homosexuality is caused only by biological factors. This could result in attempts to "correct" this way of thinking with medication and psychotherapy such as when it was believed to be a mental illness.

With sexual orientation often being such a crucial part in our personalities', and lives, but that has unfortunately been the source of discrimination of many, it is an area that deserves further exploration. Further research is vital, particularly in the vastly under investigated area of female sexuality. A definitive finding would allow for a better treatment of discriminated individuals, and a better understanding of ourselves.

\section{Author Biography}

Idalia Maciel is from Mexico City, Mexico. She will be graduating with honors in May 2018, with a Psychology major and a double minor in Spanish and Criminal Justice. Idalia has been a part of the Honors College since her freshman year at UNT. She is the Writing Coach in Dr. Barnett's Adult Development and Aging Lab, where she has co-authored one peer-reviewed journal article, has five manuscripts currently under review, and has two more in preparation. She plans to pursue a Ph.D. in experimental psychology and become a research psychologist in the area of sexuality with a focus on the LGBT population.

\section{References}

[1] Brent Slife. Taking Sides: Clashing Views on Psychological Issues. McGraw-Hill, New York, 2010.

[2] Gregory M Herek and Linda D Garnets. Sexual orientation and mental health. Annu. Rev. Clin. Psychol., 3:353-375, 2007.

[3] Evelyn Hooker. The adjustment of the male overt homosexual. Journal of projective techniques, 21(1):18-31, 1957.

[4] John Corvino. What's Wrong with Homosexuality? Oxford University Press, New York, 2013.

[5] Simon LeVay. A difference in hypothalamic structure between heterosexual and homosexual men. Science, 253(5023):1034, 1991.

[6] Simon Levay. Gay, Straight and the Reason Why. Oxford University Press, New York, 2011.

[7] David Nimmons. Sex and the brain. Discover, 15(3):64$70,1994$.
[8] Dick F Swaab and Michel A Hofman. An enlarged suprachiasmatic nucleus in homosexual men. Brain research, 537(1):141-148, 1990.

[9] DF Swaab, AK Slob, Elisabeth Judith Houtsmuller, Teus Brand, and JN Zhou. Increased number of vasopressin neurons in the suprachiasmatic nucleus (scn) of 'bisexual'adult male rats following perinatal treatment with the aromatase blocker atd. Developmental brain research, 85(2):273-279, 1995.

[10] Joel E Alexander and Kenneth J Sufka. Cerebral lateralization in homosexual males: A preliminary eeg investigation. International Journal of Psychophysiology, 15(3):269-274, 1993.

[11] Minming Zhang, Shaohua Hu, Lijuan Xu, Qidong Wang, Xiaojun $\mathrm{Xu}$, Erqing Wei, Leqin Yan, Jianbo Hu, Ning Wei, Weihua Zhou, et al. Neural circuits of disgust induced by sexual stimuli in homosexual and heterosexual men: An fmri study. European journal of radiology, 80(2):418-425, 2011.

[12] J Michael Bailey and Richard C Pillard. A genetic study of male sexual orientation. Archives of general psychiatry, 48(12):1089-1096, 1991.

[13] Frederick L Whitam, Milton Diamond, and James Martin. Homosexual orientation in twins: A report on 61 pairs and three triplet sets. Archives of sexual behavior, 22(3):187-206, 1993.

[14] Scott L. Herschberger. "biological factors in the development of sexual orientation.”. In Anthony R. D'Augelli and Charlotte J. Patterson, editors, Lesbian, Gay, and Bisexual Identities and Youth: Psychological Perspectives, pages 27-51. Oxford University Press, New York, 2001.

[15] Sandy B Primrose and Richard Twyman. Principles of genome analysis and genomics. John Wiley \& Sons, 2009.

[16] Dean H Hamer, Stella Hu, Victoria L Magnuson, Nan $\mathrm{Hu}$, Angela ML Pattatucci, et al. A linkage between dna markers on the $\mathrm{x}$ chromosome and male sexual orientation. Science, 261:321-321, 1993.

[17] Daryl Bem. The exotic-becomes-erotic theory of sexual orientation. The role of theory in sex research, pages 67-81, 2000.

[18] Ray Blanchard and Anthony F Bogaert. Homosexuality in men and number of older brothers. The American journal of psychiatry, 153(1):27, 1996.

[19] Daryl Bem and Sandra Lipsitz. Gender schema theory: A cognitive account of sex typing. Psychological review, 88(4):354, 1981.

[20] David L Raphling. The 'sissy boy syndrome' and the development of homosexuality. Journal of the American Psychoanalytic Association, 37(1):239-242, 1989. 
[21] Carla Golden. "diversity and variability in women's sexual identities.". In John Corvino, editor, Same Sex: Debating the Ethics, Science and Culture of Homosexuality, pages 107-120. Rowman Littlefield, Lanham, MD, 2015.

[22] David Sylva, Adam Safron, AM Rosenthal, Paul J Reber, Todd B Parrish, and J Michael Bailey. Neural correlates of sexual arousal in heterosexual and homosexual women and men. Hormones and Behavior, 64(4):673-684, 2013. 


\begin{tabular}{|c|c|c|c|}
\hline Factor & $\begin{array}{c}\text { Author(s) \& } \\
\text { Year }\end{array}$ & Study Design & Findings/conclusions \\
\hline \multirow[t]{5}{*}{$\begin{array}{c}\text { Brain } \\
\text { Anatomy }\end{array}$} & $\begin{array}{c}\text { Simon } \\
\text { LeVay, } 1991\end{array}$ & $\begin{array}{l}\text { Post-mortem } \\
\text { autopsy } \\
\text { comparing } \\
\text { brains of } \\
\text { homosexual } \\
\& \\
\text { heterosexual } \\
\text { men }\end{array}$ & $\begin{array}{l}\text { Found that homosexuals have a decreased size of } \\
\text { the third interstitial nucleus (INAH3), with a } \\
\text { similar size to that of women. }\end{array}$ \\
\hline & $\begin{array}{l}\text { Swaab } \\
\text { \&Hofman, } \\
1990\end{array}$ & $\begin{array}{l}\text { Morphometric } \\
\text { analysis in } \\
\text { homosexual } \\
\text { and } \\
\text { heterosexual } \\
\text { men }\end{array}$ & $\begin{array}{l}\text { Suprachiasmatic nucleus was found to be } 1.7 \\
\text { times larger in homosexuals than heterosexuals, } \\
\text { and to contain } 2.1 \text { times more cells. }\end{array}$ \\
\hline & $\begin{array}{c}\text { Swaab, Slob, } \\
\text { Houtsmuller, } \\
\text { Brand, \& } \\
\text { Zhou, } 1995\end{array}$ & $\begin{array}{l}\text { Rats treated } \\
\text { with } \\
\text { aromatase } \\
\text { inhibitor ATD }\end{array}$ & $\begin{array}{l}\text { When they reached sexual maturity, rats treated } \\
\text { with ATD pre- and postnatally demonstrated } \\
\text { bisexual behavior and 59\% more vasopressin- } \\
\text { expressing neurons in the suprachiasmatic } \\
\text { nucleus than controls. Researchers concluded } \\
\text { that the difference in the volume of the SCN } \\
\text { could be a result of the interaction of sex } \\
\text { hormones with the brain from an early age. }\end{array}$ \\
\hline & $\begin{array}{l}\text { Alexander \& } \\
\text { Sufka, } 1993\end{array}$ & $\begin{array}{l}\text { EEG studies } \\
\text { on } \\
\text { heterosexual } \\
\text { and } \\
\text { homosexual } \\
\text { men, as well } \\
\text { as females } \\
\text { while } \\
\text { performing } \\
\text { verbal and } \\
\text { spatial tasks. }\end{array}$ & $\begin{array}{l}\text { Homosexuals were found to produce a higher } \\
\text { amount of brain waves in the left hemisphere } \\
\text { than heterosexual males when performing spatial } \\
\text { tasks, while also showing less activity in the } \\
\text { right hemisphere when performing verbal tasks. } \\
\text { Homosexual males and heterosexual females had } \\
\text { similar activity during both verbal and spatial } \\
\text { tasks. }\end{array}$ \\
\hline & $\begin{array}{l}\text { Zhang et al., } \\
2011\end{array}$ & $\begin{array}{l}\text { fMRI studies } \\
\text { on } \\
\text { heterosexual } \\
\text { and } \\
\text { homosexual } \\
\text { men while } \\
\text { experiencing } \\
\text { sexual } \\
\text { disgust. }\end{array}$ & $\begin{array}{l}\text { In homosexuals, there was more brain activation } \\
\text { in the left medial frontal gyrus than in } \\
\text { heterosexuals, while heterosexual men had } \\
\text { greater activation in the left cuneus in } \\
\text { comparison to gay men when sexually disgusted. } \\
\text { It was found that homosexual and heterosexual } \\
\text { men have both similar brain regions activated, as } \\
\text { well as specific ones activated according to } \\
\text { orientation, providing support for brain } \\
\text { differentiation by sexual orientation. }\end{array}$ \\
\hline
\end{tabular}

Figure 1. Summary of meta-analysis of studies on biological basis of homosexuality 


\begin{tabular}{|c|c|c|c|}
\hline \multicolumn{4}{|c|}{ Biological Factors } \\
\hline Factor & $\begin{array}{l}\text { Author(s) } \\
\text { \& Year }\end{array}$ & Study Design & Findings/conclusions \\
\hline \multirow[t]{4}{*}{ Genetics } & $\begin{array}{c}\text { Bailey \& } \\
\text { Pillard, } \\
1991\end{array}$ & $\begin{array}{l}\text { Twin study on } \\
\text { homosexual } \\
\text { males }\end{array}$ & $\begin{array}{l}\text { For homosexuality, there was a concordance rate } \\
\text { of } 52 \% \text { between monozygotic twins (MZ), } 22 \% \\
\text { for dizygotic (DZ) twins, and } 11 \% \text { for adoptive } \\
\text { brothers. Researchers concluded childhood } \\
\text { gender nonconformity does not seem to be an } \\
\text { indicator for "genetic loading for homosexuality" }\end{array}$ \\
\hline & $\begin{array}{l}\text { Whitam, } \\
\text { Diamond \& } \\
\text { Martin, } \\
1993\end{array}$ & Twin study & $\begin{array}{l}\text { Homosexuality concordance rate of } 65.8 \% \text { for } \\
\text { MZ twins, } 29 \% \text { for DZ twins. Three sets of } \\
\text { triplets also used where in one of the sets all } \\
\text { three were concordant while in the other two } \\
\text { sets, two of the triplets were concordant. Results } \\
\text { were interpreted to support for the idea of a } \\
\text { biological basis of homosexuality. }\end{array}$ \\
\hline & $\begin{array}{l}\text { Hershberger, } \\
2001\end{array}$ & $\begin{array}{l}\text { Meta-analysis } \\
\text { of twin } \\
\text { studies }\end{array}$ & $\begin{array}{l}\text { Meta-analysis of eight twin studies on the topic } \\
\text { concluded that MZ twins had a significantly } \\
\text { higher concordance rate for homosexuality than } \\
\text { the DZ twins in six of the studies. }\end{array}$ \\
\hline & $\begin{array}{l}\text { Hamer, } \mathrm{Hu}, \\
\text { Magnuson, } \\
\text { Hu \& } \\
\text { Pattatucci } \\
\quad(1993)\end{array}$ & $\begin{array}{l}\text { DNA linkage } \\
\text { analysis on } \\
\text { families of } \\
\text { homosexual } \\
\text { men }\end{array}$ & $\begin{array}{l}\text { Thirty-three of forty homosexual pairs of siblings } \\
\text { were found to be concordant for the alleles in the } \\
\text { Xq } 28 \text { genetic marker. As a result of these } \\
\text { findings, Hamer stated that there was } 99.5 \% \\
\text { certainty that there is a gene, or several genes, on } \\
\text { the X chromosome that cause a predisposition for } \\
\text { heterosexuality and concluded that the } \\
\text { maternally linked (inherited from the mother) } \\
\text { chromosome band Xq28 was connected to } \\
\text { homosexuality. }\end{array}$ \\
\hline $\begin{array}{l}\text { Fraternal- } \\
\text { Birth- } \\
\text { Order } \\
\text { Effect }\end{array}$ & $\begin{array}{c}\text { Blanchard \& } \\
\text { Bogaert, } \\
1996\end{array}$ & $\begin{array}{l}\text { Questionnaire } \\
\text { concerning } \\
\text { family } \\
\text { background }\end{array}$ & $\begin{array}{l}\text { Possibility of being homosexual rises by } 33 \% \text { for } \\
\text { every older brother an individual has. }\end{array}$ \\
\hline
\end{tabular}

Figure 2. Summary of meta-analysis of studies on biological basis of homosexuality (continued) 
Environmental Factors

\begin{tabular}{|c|c|c|c|}
\hline Factor & $\begin{array}{c}\text { Author(s) } \\
\text { \& Year }\end{array}$ & Study Design & Findings/conclusions \\
\hline \multirow{2}{*}{$\begin{array}{c}\text { Gender } \\
\text { conformity } \\
\text { \& Exotic- } \\
\text { Becomes- } \\
\text { Erotic }\end{array}$} & $\begin{array}{c}\text { Bell et al., } \\
1981\end{array}$ & $\begin{array}{l}\text { Longitudinal } \\
\text { study }\end{array}$ & $\begin{array}{l}\text { Childhood gender conformity or nonconformity } \\
\text { was the only significant childhood predictor of } \\
\text { later sexual orientation for both men and women }\end{array}$ \\
\hline & Bem, 1997 & Meta-analysis & $\begin{array}{l}\text { Homosexual individuals, both male and female } \\
\text { were more likely to be gender nonconforming in } \\
\text { childhood than heterosexuals. } \\
\text { Studies carried out on homosexual and } \\
\text { heterosexual participants showed that } 70 \% \text { of } \\
\text { gay men and lesbian women felt different from } \\
\text { same-sex peers in childhood, while } 38 \% \text { of } \\
\text { heterosexual males and } 51 \% \text { of heterosexual } \\
\text { females felt the same way. }\end{array}$ \\
\hline $\begin{array}{c}\text { Gender } \\
\text { conformity } \\
\text { \& Exotic- } \\
\text { Becomes- } \\
\text { Erotic }\end{array}$ & Green, 1987 & $\begin{array}{l}\text { Longitudinal } \\
\text { study }\end{array}$ & $\begin{array}{l}\text { Of the children studied, } 75 \% \text { of gender } \\
\text { nonconforming boys became homosexual or } \\
\text { bisexual while only } 4 \% \text { of gender conforming } \\
\text { boys did }\end{array}$ \\
\hline $\begin{array}{l}\text { Female } \\
\text { Sexuality }\end{array}$ & $\begin{array}{l}\text { Sylva, } \\
\text { Safron, } \\
\text { Rosenthal, } \\
\text { Reber, } \\
\text { Parrish \& } \\
\text { Bailey., } \\
\text { 2010) }\end{array}$ & fMRI study & $\begin{array}{l}\text { Brain functions of men and women. show } \\
\text { category specific sex differences. Sexual arousal } \\
\text { was found to be much less category-specific for } \\
\text { females than s for males. Instead, their sexual } \\
\text { arousal was undifferentiated between erotic } \\
\text { stimuli featuring men or women, no matter their } \\
\text { preferred sex according to their sexual } \\
\text { orientation. }\end{array}$ \\
\hline
\end{tabular}

Figure 3. Summary of meta-analysis of studies on environmental basis of homosexuality 